\title{
Powerful Insights of Authentic Leadership
}

\author{
Dr. AMANY I. SHAHIN \\ Associate Professor, Faculty of Commerce- \\ Department of Management, Helwan University. \\ Email: aioshahi@hotmail.com
}

\begin{abstract}
The topics of leadership and power have attracted considerable interest from both practitioners and academics in recent years. We study the relation between Authentic Leadership (Ethics, Preferences of others, Listening to opposers, admitting mistakes, and considering the opinion of others) and Power (Coercive power, Reward Power, Legitimate Power, Expert Power and Referent Power). The study aims to identify this relation in the Egyptian environment, and to highlight the main factors influencing Egyptian public employees. Data were collected through a questionnaire survey from 105 Egyptian public employees from the Ministry of Social Security. Different age groups and different work levels were investigated. Hypotheses were tested and analyzed by means of a mean differences and a correlation analysis. It was found that Ethics is the most important authentic leadership feature in Egypt and some of the features of Authentic Leadership have a positive relation with Power in the Egyptian environment. Findings of this study provide theoretical implications and practical hints to researchers.
\end{abstract}

Keywords: Authentic Leadership, Ethics, Preferences of others, Listening to opposers, Admitting Mistakes, Considering the opinion of others, Coercive power, Reward Power, Legitimate Power, Expert Power, Referent Power.

\section{Introduction}

Leadership is the art of motivating a group of people to act towards achieving a common goal. In a business setting, this can mean directing workers with a strategy to meet the company's needs. Authentic leadership as one of the modern leadership approaches is investigated with power. Power is also deeply attached to leadership. Both, the leader's action and subordinates responses reflect the bases of power, which are regarded as legitimate and appropriate within their society.

The concept of power is considered a narrower scope of leadership. Power is the potential ability of one person to influence other people to carry out orders (Daft, 2004). Leaders who use power effectively to accomplish tasks in their organizations without relying on their job titles (positions). Kanter (1977) argued that powerful leaders rely more on personal power than job title, or credentials, to mobilize their resources, inspire creativity, and instill confidence among subordinates.

Owing to the crucial role played by power in organizations, many academics and practitioners show a high interest in studying it. Power is one of the issues that could be used to asses decision points within organizations.

Although many researchers investigated the concept of power there is a lack of studies investigating power in Egypt. The present study addresses this gap. This study explores the bases of organizational power and authentic leadership that dominates the business environment in Egypt. 


\section{The New Leadership Approaches}

House's (1977) review rekindled interest in charismatic leadership. Subsequent research and theorizing has been concerned with such issues as the characteristics of charismatic leaders, the circumstances under which charismatic leadership is likely to arise and the effects of charismatic leadership on organizational performance and the well-being of followers (House and Shamir, 1993; Bennis and Nanus, 1985; Tichy and Devanna, 1986: Sashkin, 1988; Conger \& Kanungo, 1998). An alternative approach to inspirational leadership was developed by Burns (1978). Based on the study of political leaders, Burns (1978) made the influential distinction between transactional and transformational leadership. According to Burns, transactional leadership occurs when one person takes the initiative in making contact with others for the purpose of an exchange of valued things. Transformational leadership, on the other hand, occurs when one or more persons engage with others in such a way that leaders and followers raise one another to higher levels of motivation.

The concepts of transformational and transactional leadership were later applied to organizational leadership by Bass (1985). However, Bass took a different view from Burns concerning the relationship between transformational and transactional leadership. Whereas Burns saw transformational and transactional leadership as two mutually exclusive forms of leadership, Bass argued that the same leader could exhibit both patterns of leadership.

\section{The Concept of Authentic Leadership}

The Authentic leadership stems from the transformational leadership. It evolves around the same idea. Traditional leadership approaches place power at the core of leadership, authentic leadership scholars would argue that benevolence is the value that is central to effective authentic leadership (Qiua et al, 2019).

Specifically, an authentic leader is defined as one who draws on his own personal experiences( thoughts, emotions, needs, wants, preferences, or beliefs) and who acts according to his true self, expressing oneself in ways that are consistent with inner thoughts and feeling (Harter, 2002).

Geroge (2003) defined the concept of authentic leadership as a process that starts with the leader's awareness that allows him to build positive relationships, inspire and encourage employees in the right ways. An atmosphere of openness is used. According to George, one of the core qualities of a leadership role is authenticity. It requires a leader to be self-aware and have the ability to recognize and acknowledge his own strengths and weaknesses. Authentic leadership revolves around the leader's ethical behavior. It emphasizes how a leader can gain legitimacy and build trust through developing honest relationship with followers (Avolio \& Gardner, 2005).

Walumbwa et. al (2008) defined Authentic leadership as a pattern of leader behavior that draws upon and promotes both positive psychological capacities and a positive ethical climate to foster greater selfawareness, an internalized moral perspective, balanced processing of information and relational transparency on the part of leaders working with followers, fostering positive self-development.

Authentic leadership is highly correlated to creativity (Shanga et al, 2019) and it helps human resources to attain more authenticity and credibility in the organization (Gilla et. al, 2018). It was found recently that authentic leadership reduces leaders' stress and increases their work engagement. (Weiss et al 2018)

\section{The Process of Authentic Leadership}

Authentic leadership is a value-based leadership style (Gardner et al. 2011). This value-based view can be comprehended from the four dimensions of authentic leadership. 1) Self-awareness means that authentic leaders are clear about their strengths and weaknesses. This clarification enables authentic leaders to 
clarify their true values and to become aware of the consistency between their true values and their behaviors (Kernis, 2003; Kernisa and Goldman, 2006). An internalized moral perspective encourages authentic leaders to make decisions following their moral principles or true values even in highly stressful situations (Avolio and Gardner 2005). Balanced processing of information enables authentic leaders to deliberate others' different points of views that question their deeply held positions. This processing encourages authentic leaders to have an open mind (Kernis 2003).4) Relational transparency, enables authentic leaders disclose their inner feelings and thoughts (Kernis 2003; Goldman, 2006). From this disclosure, followers can more easily detect their leaders' underlying true values.

Bensen et. al (2017) identifies that Authenticity is built through four main points : a) Self-awareness of strengths and weaknesses, emotions and values; b) Fair processing of relevant information or objective acceptance of attributes; c) Authentic behavior or acting according to your true self; d) Relational authenticity: striving to achieve openness and honesty in intimate relationships.

Finally, according to Towler, (2019, Febraury 17) Authentic leadership involves the following steps:

- Self-awareness: An authentic leader shows self-awareness through reflecting on their own strength and weakness and values.

- Relational transparency: An authentic leader demonstrates relational transparency when they openly share their own thoughts and beliefs yet they do not display their emotions to followers

- Authentic leadership are balanced in their approach because the solicits opinions from subordinates and welcome opposing views

- Authentic leadership displays a strong moral code that they demonstrate in their relationship and decision making.

Authentic leadership is an approach of leadership_in building trust and generating enthusiastic support from their subordinates, authentic leaders are able to improve individual and team performance.

\section{Authentic Leadership Positivity}

Authentic leadership is an example of positive leadership that we use as a positivity in leadership studies (Alvessona \& Einolab, 2019). Authentic leadership is assumed to motivate followers and promote individual, team, and organizational effectiveness (Gardner et al., 2011). It is supposed to lead to all kinds of positive outcomes. Follower are assumed to exert greater effort, engage in organizational citizenship, experience improved attitudes. They are assumed also to have increased trust, positive emotions, wellbeing, higher motivation, engagement, more satisfaction, greater empowerment, and moral development (Caza \& Jackson, 2011).

Authentic leaders demonstrate confidence, hope, and optimism in the workplace (Gardner, Avolio, 2005). These positive attitudes and emotions may cause leaders to foster positive emotional and cognitive development among their followers, resulting in more citizenship behaviors. Also, authentic leaders objectively evaluate all relevant information when making a decision; they create a fair and open environment in the workplace. In such a workplace, employees are more aware of the importance of helping other people and encouraged to do so (Walumbwa, 2010).

Accordingly, authentic leadership had relations with many categories. The relationship between authentic leadership and customer-oriented OCB was partially mediated by trust in leaders. (Qiua, et al. 2019). However, for students authentic leaders are those who are characterized by higher self-awareness, relational transparency, internalized morality and balanced processing. They are capable of enhancing students' promotion-focused behavior because they can put students in a situation where they develop a passion for participating in a challenging task (Walumbwa et al., 2008). 
Being able to develop strong power sources is essential in the promotion of students' ideals and advancement at work (Hollander \& Offermann, 1990). Actually students' promotion-focused behavior mediates the relationship between authentic leadership and their creativity (Shang et al. 2019).

Authentic leadership reduces leaders' stress and increases their work engagement. However, while prior research has demonstrated authentic leadership's general effectiveness in instilling positive follower behaviors, the effects of authentic leadership on leaders themselves remain poorly understood (Gardner et al., 2011).

\section{The relationship between Authentic Leadership \& Power}

Some authentic leaders who desire high power, wealth, and status may lead to negative follower outcomes. They might become involved in unethical behaviors to guarantee their fulfillment of high power needs, especially when they feel threatened or challenged by their followers. With that regard, the positive relationship between authentic leadership and followers' performance could be reversed when leaders are driven by their high power values (Qiua et al. 2019). Authentic leaders with high power values seem to represent the dark side of authentic leadership. However, authentic leaders with high benevolence values promote followers performance ( $\mathrm{Qu}$ et al. 2018). Security in organizations should consider recruiting and developing authentic leaders to foster positive safety climates and risk management (Nelson et al 2013).

\section{Powerful Insights}

Power is difficult to define (Lukes, 1986). Power could be defined as an individual's relative capacity to modify others' states by providing or withholding resources or administering punishments (Keltner et al., 2003). Rahim (1989) defines power as "the ability of one party to change or control the behaviour, attitudes, opinions, objectives, needs, and values of another party. Krausz (1986) argued power is the ability to influence the actions of others, individuals or groups, to persuade and encourage others to attain specific goals or to engage in specific behaviour. French and Raven (1959; cited in Goltz, 2003) defined power as the potential ability of one individual to influence another individual within a certain system. Analysis of the previous definitions of power, and many other definitions, shows the following:

Firstly, It is the key word here when we define power is the ability to influence others. Secondly, to influence others, one may depend on his/her ability to provide or withhold resources or administer punishments. Finally, to influence others, one may depend on some shared objectives, opinions, values, and needs.

Hence; defining power as a concept is not enough, researchers and practitioners need to know the sources or bases of power. French and Raven (1959) stated that the types of power are - coercive, reward, legitimate, expert, and referent. This still appears to be fairly representative and popular in application (Frost \& Stahelski, 1988; Rahim, 1989, cited in: Rahim et al., 2001). Goltz (2003) added the wellrecognized types of power were identified by French and Raven (1959).

The French-Raven power bases are as follows (Rahim et al., 2001: 194):

1. Coercive power is based on subordinates' perception that a superior has the ability to punish them if they fail to conform to his/her influence attempt.

2. Reward power is based on the perception of employees that a superior can reward them for desired behavior.

3. Legitimate power is based on the belief of the subordinates that a superior has the right to prescribe and control their behavior.

4. Expert power is based on subordinates' belief that a superior has job experience and special knowledge or expertise in a given area. 
5. Referent power is based on subordinates' interpersonal attraction to and identification with a superior because of their admiration or personal liking of the superior.

The first three bases can be reclassified as position power, while the remaining two bases can be classified as personal power.

Trust and high quality leader-follower relations are fundamental to linking authentic leader behavior to follower behaviors, yet, to date empirical evidence does not exist. (Erkutlu \& Chafra,2013)

\section{Power in the Egyptian Culture}

Many researchers investigated leadership in the Egyptian Context. Centralization of power seems to be a dominant factor of the Egyptian culture, recent researches show a trend towards participation, as a way of sharing decision making. Badran and Hinings (1981) found that Egyptian organizations are highly structured and highly centralized. Palmer et al. (1985) found that Egyptian officials attempted to concentrate as much authority as possible in their hands and they tended to resist the delegation of authority. They considered three themes, the first was historical in nature, the second stressed the patriarchal nature of the Egyptian culture, and the third theme considered centralization as motivated by personal concerns of power. According to Hofstede (1980) Arab countries such as Egypt are characterized by high power distance and high uncertainty avoidance. Hickson and Pugh (1995) wonderfully described the Arab culture as having two paradoxes, first Arabs are disposed to handle authority with high power distance. Secondly, they pursue their own individual interests yet do so by collectivistic means through personal relationships.

Other researchers found that Egyptian managers consider participation as one of the most important managerial aspects in organizations. Elgamal (1993) found differences in managerial profiles which revolved around planning and issues of participation. Parnell and Hatem (1999) compared the Egyptian and American management styles. The study was conducted at the American Chamber of Commerce in Egypt. The Egyptian sample reflected the desire for participative style of leadership.

Atiyah (1992) concluded that the main features of organizations and management in Arab countries are over centralization and emphasis on control. However, he notes that the results with respect to leadership styles of Arab managers are conflicting. Some follow an authoritarian style, which could be linked to the traditional leader in Arab societies, while others follow a consultative style.

Actually we find that some researchers identified the existence of concentration of power as a main dominant factor controlling public organizations in Egypt and therefore conclude that it has a wide impact on leadership (Palmer et al, 1985; Badran and Hinings, 1981; Kabasakal and Bodour, 2002) while others referred to the existence of participation for Egyptian leadership styles (Elgamal, 1993; Parnell and Hatem, 1999).

\section{Methodology}

This research is a hypotheses testing research. Convenience sampling was used to collect data. Convenient sampling was used because it was considered quick and less expensive. The research aims to investigate the relationship between Power (Coercive power, Reward power, Legitimate power, Expert power, Referent power) and Authentic leadership

A likert scale was used for the first 5 items. (1) referred to strongly agree (2) agree (3) neutral (4) disagree and (5) strongly disagree. This indicated that (1) strongly agree referred to a very high degree of acceptance or very low degree of refusal, while (5) strongly disagree referred to a very low degree of acceptance a very high degree of refusal. 
Authentic Leadership in this research consists of the following: Leadership ethics, Preference of others interests, Listening to employees, Admitting mistakes, and Concerning others opinions. While, power consists of Coercive power, Reward Power, Legitimate Power, Expert Power, and Referent Power

\section{Research Hypotheses}

This study aims to test the following hypotheses:

H1 Leadership ethics is the most important feature of Authentic Leadership in the Egyptian Culture, While, Considering others opinions is the least important feature

H2 There is a positive correlation between Coercive Power and Authentic leadership (Leadership ethics, Preference of others interests, Listening to employees, Admitting mistakes, and Concerning others opinions).

H3 There is a positive correlation between Reward Power and Authentic leadership (Leadership ethics, Preference of others interests, Listening to employees, Admitting mistakes, and Concerning others opinions).

H4 There is a positive correlation between Legitimate Power and Authentic leadership (Leadership ethics, Preference of others interests, Listening to employees, Admitting mistakes, and Concerning others opinions).

H5 There is a positive correlation between, Expert Power and Authentic leadership (Leadership ethics, Preference of others interests, Listening to employees, Admitting mistakes, and Concerning others opinions).

H6 There is a positive correlation between Referent Power and Authentic leadership (Leadership ethics, Preference of others interests, Listening to employees, Admitting mistakes, and Concerning others opinions).

The survey included different occupations and age groups of Egyptian employees from the Ministry of Social Security. Questionnaires were distributed among the employees. They were translated into Arabic. The results were a total of 105 usable responses from distributed questionnaires. The Ministry of Social Security the Rehabilitation Department in Egypt was investigated. It is the government entity responsible for social security affairs.

Table 1. Question and Related variables

\begin{tabular}{|l|l|}
\hline Questions & Variables \\
\hline \hline 1)Take actions that reflect his ethics & \\
2) Usually prefers the benefit of the group \\
3) listens carefully to those who oppose him \\
4)Admits his mistakes \\
5) Doesn't emphasize his own point of view at the \\
expense of others
\end{tabular}

As the hypotheses were mentioned previously we are going to see how they are investigated by variables. 
Table 2 Hypotheses and Variables investigated

\begin{tabular}{|c||c|}
\hline H1 & Q1-5 \\
\hline \hline H2 & Q.1and 6-10 \\
\hline H3 & Q.2 and 6-10 \\
\hline H4 & Q.3 and 6-10 \\
\hline \hline H5 & Q.4and 6-10 \\
\hline \hline H6 & Q.5and 6-10 \\
\hline
\end{tabular}

The questionnaire was divided into two sections. The first section was descriptive. It included information about the type of work, age and experience. The second section included information about Authentic Leadership (Ethics, Preferences of others, Listening to opposers, Admitting mistakes, and considering the opinion of others) and Power (Coercive, Reward, Legitimate, Expert and Referent).

A Mean Comparison was used to consider the level of importance of Leadership ethics and Preference of others interests in the Egyptian Culture. Then a correlation analysis was conducted to measure the association of features of Authentic Leadership and power as independent variables on the Egyptian employees' in The Ministry of Social Security

Firstly, a Mean Comparison was used to compare the means of the different features of Authentic Leadership, it was necessary to know the most important and the least important feature. Table 3 shows the mean comparisons

Table 3 Mean comparisons of Authentic Leadership features

\begin{tabular}{|c|c|c|c|c|c|}
\hline & Ethics & $\begin{array}{c}\text { Preference } \\
\text { of others }\end{array}$ & $\begin{array}{c}\text { Listening to } \\
\text { opposers }\end{array}$ & $\begin{array}{c}\text { Admitting } \\
\text { Mistakes }\end{array}$ & $\begin{array}{c}\text { Considering } \\
\text { others } \\
\text { opinion }\end{array}$ \\
\hline Mean & 4.410 & 4.3619 & 3.8571 & 3.8095 & 4.1429 \\
\hline $\mathrm{N}$ & 105 & 105 & 105 & 105 & 105 \\
\multirow{2}{*}{ Std.Deviation } & .7030 & .68112 & .91387 & .98151 & 1.02309 \\
\hline
\end{tabular}

Table 3 shows that Ethics has the highest Authentic leadership feature and is considered the most important with a mean 4.410, while, Admitting mistakes is the least important with a mean of 3.8095. The Second in importance is the Preference of others, the third is Considering others opinions and the forth is Listening to opposers.

This indicates that our first hypothesis is partially accepted. Secondly, a correlation analysis was conducted to measure the other hypotheses. The idea of correlation is one of the basic in the elaboration of bivariate relationships (Bryman and Cramer, 1998).

Correlation indicates the strength and direction (positive or negative) of the relationship between a pair of variables (Amin, 2008). In our study we will use Pearson Product Moment Correlation because this measurement is suitable for our variables which are considered interval.

Tables 4 show the Correlation analysis. 
Table 4 The correlation between Authentic Leadership Features and Power

\begin{tabular}{|c|c|c|c||c|c|}
\hline $\begin{array}{c}\text { Features of } \\
\text { Authentic } \\
\text { Leadership }\end{array}$ & $\begin{array}{c}\text { Leadership } \\
\text { ethics }\end{array}$ & $\begin{array}{c}\text { Preferring } \\
\text { others } \\
\text { interests }\end{array}$ & $\begin{array}{c}\text { Listening to } \\
\text { opposers }\end{array}$ & $\begin{array}{c}\text { Admitting } \\
\text { mistakes }\end{array}$ & $\begin{array}{c}\text { Considering } \\
\text { others opinions }\end{array}$ \\
\hline \hline Coercive & .114 & .022 & $.224 *$ & -.038 & -.064 \\
\hline Sig.(2 tailed) & .247 & .825 & .021 & .701 & .518 \\
\hline \hline Reward & $.193 *$ & $.219 *$ & $.407 * *$ & -.172 & .015 \\
\hline Sig.(2 tailed) & .048 & .025 & .000 & .080 & .876 \\
\hline Legitimate & .023 & .108 & -.128 & .005 & .069 \\
\hline \hline Sig.(2 tailed) & .812 & .272 & .193 & .956 & .485 \\
\hline \hline Expert & .065 & .107 & -.084 & .046 & -.054 \\
\hline \hline Sig.(2 tailed) & .513 & .275 & .394 & .640 & .585 \\
\hline \hline Referent & $.242 *$ & .170 & .165 & -.074 & -.020 \\
\hline \hline Sig.(2 tailed) & .013 & .083 & .092 & .453 & .839 \\
\hline
\end{tabular}

** Correlation is significant at the 0.01 level (2-tailed).

*Correlation is significant at the 0.05 level (2-tailed).

Table 4 shows that Coercive power does not have a relationship with Leadership ethics, Preferring others interests, Admitting mistakes and Considering others opinions. While, the Listening to opposers is related to Coercive Power at .224* Sig. at .021. So our second hypothesis is partially accepted.

Reward power does not have a relationship with Admitting Mistakes and Considering Others Opinons. Actually, it has a relation with Ethics at .193** Sig. at .048, Preferring Others interests at .219* Sig. at .025 and Listening to Opposers at $.407 * *$ Sig at .000. Reward is very important for the Egyptian employees. When leaders are Ethical and prefer the interests of others they are expected to reward their employees. So our third hypothesis is partially accepted.

Legitimate and Expert power do not have any relationship with any of the Authentic Leadership features. The fourth and fifth hypotheses are rejected. However, Referent power is only related to Leadership ethics the other Authentic Leadership features were not related to it. Referent power is related to Ethics at .242* Sig at .013. Employees see their leader as a guide they are attracted and admire him.

This indicates that our sixth hypothesis is partially accepted.

\section{Discussion}

The results of the study supported some of our hypotheses. The Mean Comparison indicates that Leadership ethics is the most important Authentic Leadership feature in the Egyptian environment while, Admitting mistakes is the least important.

According to the correlation analysis, the Authentic Leadership Features: Leadership ethics, Preference of others interests and Listening to opposers, are correlated with Coercive power, Reward power and referent power.

Leadership ethics is correlated to Reward power and Referent power. The Egyptian employee ensures that they are rewarded when their leader has ethical characteristics, they feel more comfortable and secure and this could increase their productivity. Ethics is also correlated with referent power. This indicates that the employees are attracted to their leaders and consider them charismatic. 
Preference of others interests, are also related to Reward. Indicating that the Egyptian employees feels secure and will be rewarded when their leader prefers other employees interests. Listening to opposers seems to be very important in the Egyptian culture. It is related to Coercive and this indicates that leaders punish and give orders according to accurate listening. However, Reward power is also related to Listening to opposers. It increases leaders awareness and realization to what is around them, and it increases their ability to reward employees.

Admitting mistakes and Considering others opinions as Authentic leadership features do not have any relation with Power. This indicates that they do not have any effect in the Egyptian culture. Authentic Leadership exists in the Egyptian environment. Leadership ethics, Preference of others interests and Listening to opposers are the only Authentic leadership features which exists in the Egyptian culture. However, Admitting mistakes and Considering others opinions did not have any relation with Power in the Egyptian culture.

\section{Conclusion \& Recommendations}

The study investigates the features of Authentic Leadership and its relation with Power. This is essential to investigate this effect to increase the Egyptian employee's productivity. However, considering this is very important to keep the organization successful. It is important to consider the following:

- As a leader in the Egyptian culture it is necessary to emphasize on Leadership ethics, Preference of others interests and Listening to opposers. In order to attract employees and increase their productivity.

- Reward is very important for the Egyptian employee. Considering reward whether financially or nonfinancially is essential for productivity.

- Coercive power also is important as it gives a sign of equity

- Referent power is essential as it indicates that the employees are attracted to their leaders and consider them charismatic. The leaders have a great ability to motivate the employees and inspire them to work harder.

- Create a boundary for employees so that employees work within.

Further research is needed to illustrate authentic leadership in Egypt and the policies required to direct and encourage productivity in Egypt, whether in the public or private sectors. More investigations may be needed to elicit more information on productivity. This issue is worthy of further research.

\section{References}

Mats, A. \& Katja, E. (2019). Warning for excessive positivity:Authentic leadership and other traps in leadership studies, The Leadership Quarterly,30 :383-395

Rabea, A. O. (2008). Statistical Analysis for different variables by using SPSS, Egypt: Monofya University (In Arabic)

Avolio, B. J., \& Gardner, W. L. (2005). Authentic leadership development: Getting to the root of positive forms of leadership. The leadership quarterly,16 (3): 315-338.

Atiyah, H.S. (1992). Research Note: Research in Arab Countries, Organization Studies, 13(1):105-110

Badran, M. \& Hinings, B. (1981). Strategies and Administration Control and Contextual Constraints in a less developed Country: The Case of Egyptian Enterprises, Organization Studies 2(1):3-21

Bass, B. M. (1985). Leadership and Performance Beyond Expectations, London:Collier Macmillan.

Bennis, W. \& Nanus, B. (1985). Leaders: The strategies For Taking Charge, New York,,,Harper \& Row.

Fabiana, B., Edivandro, T., Francisco, F. \& Pereira, A. (2017). Authentic leadership and knowledge management, Gest. Prod., São Carlos, 24(1):. 2-14

Bryman, A. \& Carmer, D. (1998). Quantitative Data Analysis With SPSS Release 10 for Windows, East Sussex: Routledge. 
Burns, J. M. (1978). Leadership, New York: Harper \& Row,

Conger, J. A. \& Kanungo, R. N. (1998). Charismatic Leadership in Organizations London: Sage

Caze, A. \& Jackson, B. (2011). Authentic Leadership in Bryman D. Collinson, K. Grint, B. Jackson \& M. Uhil-Blen (eds)The Sage Handbook of Leadership (pp.352-364) London, Sage.

Richard, D. L.(2004). Organization Theory and Design, London:

Thomason South Western,

Elgamal,M. A. (1993). An Investigation of the Managerial Practices of Egyptian Managers and Implications for Effectiveness, Arab Management Group Proceedings, Arab Management Conference, University of Brsdford, U.K,6-8 July.

Hakan, E. \& Jamel, C. (2013). Effects of trust and psychological contract violation on authentic leadership and organizational deviance, Management Research Review, 36 (9): 828 - 848

French, J. R. P., Jr., \& Raven, B. (1959). The Bases of Social Power. In D. Cartwright (Ed.), Studies in social power (pp. 150-167). Ann Arbor, MI: Institute for Social Research.

Frost, D. E., \& Stahelski, A. J. (1988). The Systematic Measurement of French and Raven's Bases of Social Power in Workgroups. Journal of Applied Social Psychology, 18: 375-389.

Gardner, W. L., Cogliser, C. C., Davis, K. M., \& Dickens, M. P. (2011). Authentic leadership: A review of the literature and research agenda. The Leadership Quarterly, 22(6): 1120-1145

George, B. (2003). Authentic leadership: Rediscovering the secrets to creating lasting value. New York: John Wiley \& Sons.

George, B., Sims, P., McLean, A. N., \& Mayer, D. (2007). Discovering your authentic leadership. Harvard business review, 85(2): 129

Carol, G., William, G., Johannes, C. \& Kathleen, V. (2018). Using theory on authentic leadership to build a strong human resource management system, Human Resource Management Review, 28:304-314

Sonia, G. M., (2003). Toward an Operant Model of Power in Organizations. The Behavior Analyst,26 (1) (Spring); 131-150.

Harter, S. (2002). Authenticity. In C. R. Snyder, \& S. Lopez (Eds.). Handbook of positive psychology (pp. 382-394). Oxford, UK: Oxford University Press

Hickson, D.J. \& Pugh, D.S (1995). Mangement Worldwide: The Impact of Sociatel Culture on Organization Around the Globe, London: Penguin

Hofstede, G. (1980). Culture's Consequences International Differences in Work Related Values, Biverly Hills: C.A:Sage

Hollander, E. P. \& Offermann, L. R. (1990). Power and leadership in organizations relationships in transition, TheAmericanPsychologist,45(2):179-189.

House, R. J. \& Shamir, B. (1993). Toward the integration of transformational, charismatic and visionary theories, in Chemers, M.M. and Ayman, R, Leadership Theory and Research: Perspectives and Directions, Academic Press: Orlando, FL, pp.577-594.

Kabbasakal, H. \& Bodour, M. (2002). Arabis Cluster: A Bridge Between East and West, Journal of World Business, 37(1):60-67

Kanter, R. M. (1977). Men and Women of the Corporation. New York: Basic Books.

House, R. J. (1977). A 1976 theory of charismatic leadership, in Hunt, J. G. and Larson L. L. (Eds.) Leadership: The Cutting Edge, Carbondale:Southern Illinois University Press:, pp.189-207.

Dacher, K., Deborah, G. H. \& Cameron, C. (2003). Power, Approach, and inhibition,. Psychological Review. 110 (2) : 265-284.

Kernis, M. H. (2003). Toward a conceptualization of optimal selfesteem. Psychological Inquiry, 14, 1-26.

Kernis, M. H., \& Goldman, B. M. (2006). A multicomponent conceptualization of authenticity: Theory and research. In M. P. Zanna (Ed.), Advances in experimental social psychology (pp. 283-357). New York: Academic Press.

Krausz, R. (1986). Power and leadership in Organizations, Transactional Analysis Journal,16:85-91.

Lukes, S. (1986) Power. New York: New York University Press

Nielsen, Birkelan, M., Kathry, E. J. \& Gerry, L. M. (2013). Authentic leadership and its relationship with risk perception and safety climate, Leadership \& Organization Development Journal, 34( 4): 308 325 
Palmer, M., Yassin, E., \& Leila, A. (1985). Bureaucratic Flexibility and Development in Egypt, Public Administration and Development, 15(4):323-337

Parnell, J.A. \& Hatem, T. (1999). Cultural Antecedents of Behavioral Differences Between American and Egyptian Managers, Journal of Management Studies, 36(3):399-418

Shaoping, Q., Amin, A., Larry, D. M., \& Ruijuan, Z. (2019). The effect s of authentic leadership on trust in leaders ,organizational organizational citizenshipbehavior, andservicequalityintheChinesehospitalityindustry, Journal of Hospitality and Tourism Management, 40, pp.77-87

Elly, Q.Y., Marie, D.T., Mi, Z. \& Gergana, T. (2019). Should Authentic Leaders Value Power? A Study of Leaders' Values and Perceived Value Congruence, Business Ethics 156:1027-1044

Afzalur, R. M. (1989). Relationships of Leader Power to Compliance and Satisfaction with Supervision: Evidence from a National Sample of Managers, Journal of $\quad$ Management 15:545-557.

Afzalur, R. M.. David, A. \& Clement, P. (2001). A Structural Equations Model of Leader Power, Subordinates' Styles of Handling Conflict, and Job Performance., The International Journal of Conflict Management 12(3):191-211

Sashkin, M. (1988). The visionary leader, in Conger, J. A. and Kanungo, R. N. (eds.) Charismatic Leadership: The Elusive Factor in Organizational Effectiveness, Jossey-Bass: San Francisco, pp.123160.

Yufan, S., Melody, C.P.M, Jun, X. \& Xiji, Z. (2019). Authentic leadership and creativity in China: The role of students' regulatory-focused behaviors and supervisors 'power sources, Thinking Skills and Creativity, 34:1-15

Tichy, N. M. \& Devanna, M. A. (1986). The Transformational Leader: The Key to Global Competitiveness, New York.: John Wiley

Annette, T. (2019) The Power of authentic leadership: How legitimacy, ethics, and positive psychology drive organizational performance. Online at https://www.ckju.net/en/dossier/power-authenticleadership-how-legitimacy-ethics-and-positive-psychology-drive-organizational-performance

Walumbwa,F., Avolio,B., Gardner,W.,Wernsing,T.,\&Peterson,S.(2008).Authentic leadership:Development and validation of a theory-based measure,.Journalof Management,34(1):89-126.

Walumbwa,F.O.,Wang,P.,Wang,H.,Schaubroeck,J.,\&Avolio,B.J.(2010). Psychological processes linking authentic leadership to follower behaviors.The Leadership Quarterly, 21:901-914.

Matthias, W. R., Backmann, S. \& Martin, J. H. (2018). Authentic leadership and leaders' mental wellbeing: An experience sampling study, The Leadership Quarterly ,29:309-321. 